\title{
Fred i calor instantanis per mètodes químics
}

\author{
Josep Corominas \\ Escola Pia de Sitges \\ coromi6@pie.xtec.es
}

Escalfar o refredar ho fem a casa amb un combustible, com el gas o amb electricitat si tenim cuina i calefacció elèctrica. Per refredar, tant el frigorífic com l'aparell d'aire condicionat tenen un líquid de refrigeració impulsat per un motor elèctric.

Però com podríem refredar o escalfar si estem lluny d'aquestes comoditats?

\section{OBJ ECTIU}

Es tracta que observis canvis químics que absorbeixen o desprenen calor i que, a partir de les teves observacions, puguis explicar el fonament de determinats objectes casolans emprats per refredar o escalfar.

\section{PASSOS A REALITZAR}

\section{Fred instantani}

Posa uns $50 \mathrm{~mL}$ d'aigua en un vas de precipitats. Pren nota de la temperatura.

Dissol en l'aigua uns $20 \mathrm{~g}$ de nitrat d'amoni. Comprova com baixa la temperatura tot remenat suaument amb el mateix termòmetre.

Què contenen les bosses de "fred instantani"?

Examina ara la composició d'una bossa de "fred instantani" o "cold pack": la trobaràs escrita en l'envoltori. Pots comprovar que dins hi ha nitrat 0 clorur d'amoni sòlid i una bossa amb aigua.

Quant s'ha d'utilitzar es dóna un cop fort a la bossa per rebentar la bossa interior amb aigua que, en contacte amb el clorur d'amoni, el dissolt.

\section{Calor instantani}

Posa aigua en un tub d'assaig, aproximadament fins a la meitat. Pren nota de la temperatura

Afegeix ara a l'aigua del tub d'assaig una espàtula amb òxid de calci. Comprova com hi ha un augment de la temperatura.
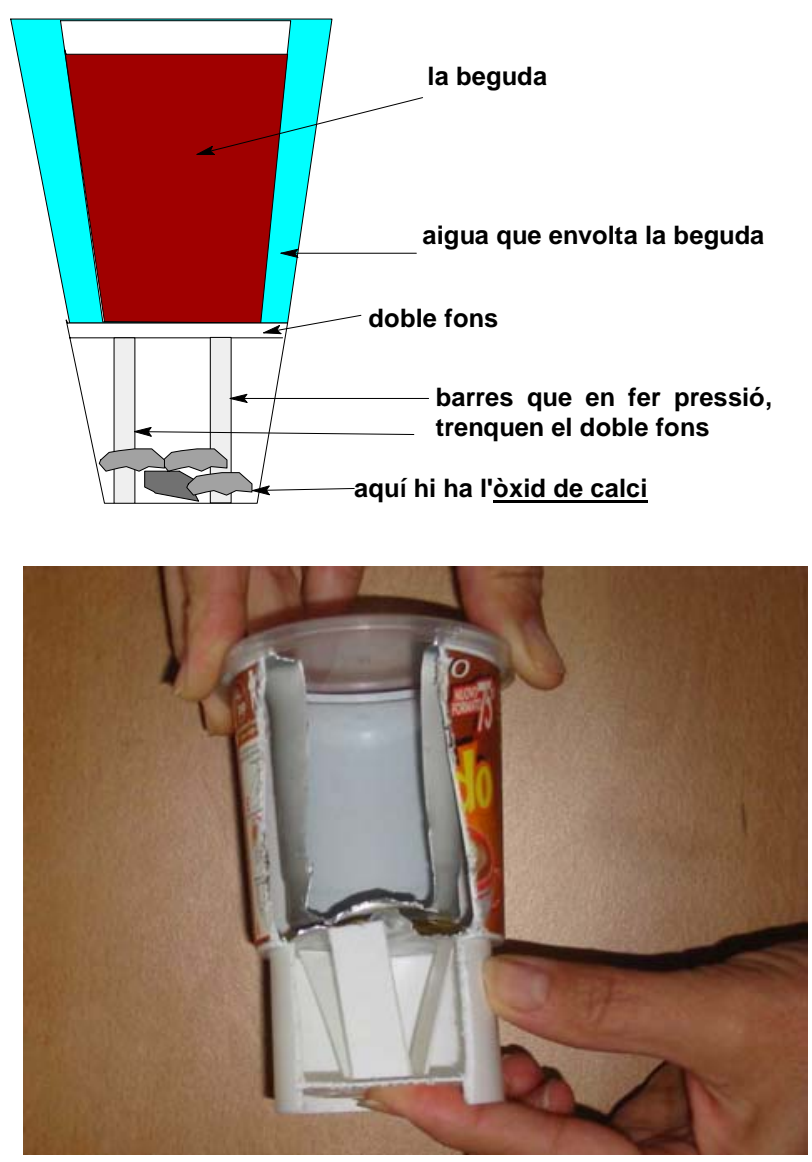

Figura 1. Diagrama i fotografia de l'interior del recipient. 
A Itàlia, és molt fàcil de trobar begudes com el famós capuccino en vasos on, fent una pressió en el fons del vas, la beguda s'escalfa automàticament!

El vas té un triple fons: un recipient conté òxid de calci, un segon conté aigua i el tercer el vas amb la beguda (infusió, cafè...). La pressió trenca la membrana que separa el $\mathrm{CaO}$ de l'aigua i la reacció exotèrmica escalfa la beguda.

\section{Investigant les "bosses escalfamans" per a excursionistes i esquiadors}

Aquestes bosses es fan servir per escalfar mans o peus posant-les, per exemple, dins dels guants. Es troben en magatzems i botigues d'articles esportius.

Composició indicada: ferro, aigua, cel-lulosa, vermiculita, carbó actiu, sals, (en la marca Decathlon, la vermiculita és substituïda per serradures).

Els fabricants assenyalen que la temperatura pot arribar entre els $57^{\circ} \mathrm{C}$ i els $69^{\circ} \mathrm{C}$.

Per fer-la servir, es treu d'un embolcall de plàstic tancat al buit.

La calor que desprèn ha de ser deguda a la oxidació de ferro en pols. Això explica les propietats magnètiques. L'oxidació comença tot seguit es treu la bossa del seu embolcall al buit, en entrar el ferro en contacte amb l'oxigen de l'aire.

La vermiculita s'expandeix al mullar-la (degut a l'aigua que hi ha entre les capes d'aquest mineral argilós) i també s'expandeix en escalfar-la (degut a l'aigua que queda entre les capes i que en passar a vapor augmenta la pressió).

\section{Bosses per escalfar, reutilitzables múltiples vegades}

En l'interior de petites bosses de plàstic transparent hi ha un líquid i una peça metàl-lica. Quan es vol utilitzar es doblega la peça metàl-lica i la bossa s'escalfa fins uns $50^{\circ} \mathrm{C}$.

Un cop s'ha refredat, es bull uns minuts la bossa dins un recipient amb aigua, es deixa refredar a poc a poc i ja està a punt per tornar a ser usada.

La bossa conté una dissolució sobresaturada d'acetat de sodi. La cristal.lització de l'acetat de sodi és un procés molt exotèrmic (la temperatura màxima pot arribar a uns $50^{\circ} \mathrm{C}$ ).

El procés és reversible: és suficient posar la bossa usada amb l'acetat de sodi cristal-litzat en aigua bullent, perquè es torni a formar una dissolució sobresaturada que es queda així en refredar.

\section{BIBLIOGRAFIA}

T. Lister (compilador) (1995). Classic Chemistry Demonstrations. London: The Royal Society of Chemistry (1993-1994). Versió en castellà: T. Lister (compilador) (2002) Experimentos de química clásica. Madrid: Ed. Síntesis.

B. Shakhashiri (1983). Chemichal Demonstrations. A handbook for teachers of chemistry. University of Winsconsin Press.

Calentador químico para biberones. Revista electrònica El rincón de la ciencia $n^{0} \quad 20$ : http://rinconciencia.go.to

R. Silberman. (2004). J. Chem. Ed. vol 81, $\mathrm{n}^{\circ}$ 1. January. 